DOI https://doi.org/10.18551/rjoas.2018-09.18

\title{
INTERFERENCE OF ORGANIZATIONAL COMMUNICATION IN THE RELATIONSHIP BETWEEN ENTREPRENEURIAL ORIENTATION AND CORPORATE PERFORMANCE
}

\author{
Fortunisa Ananda*, Sedyowidodo Urip, Djamaris Aurino Rilman Adam, \\ Novianti Mirsa Diah \\ Bakrie University, Indonesia \\ *E-mail: ananda.fortunisa@bakrie.ac.id
}

\begin{abstract}
This research aimed to determine the relationship between entrepreneurial orientation and corporate performance in State Owned Corporations (SOEs) through Organizational Communication as the moderating variable. This research was a verificative descriptive research. Data were collected through a survey on SOEs in Indonesia. The results showed that in the SOE management structure, communication processes is based on efforts to develop capacity continuously and the ideas freely direct the achievement of organizational performance, formulated according to multidisciplinary assumptions. Communication management in SOEs based on adult and independent communication assumptions with information technology support directs the capacity of employees to produce an optimal organizational performance.
\end{abstract}

\section{KEY WORDS}

Entrepreneurial orientation, performance, organizational communication, management.

The measurement of the success of companies is increasingly growing in this competitive era. The financial dimension is considered no longer relevant to competitiveness. Fox (2005) proposed financial and non-financial indicators. Meanwhile, Kaplan \& Northon (1996) and Kaplan (2001) showed that perspectives to measure the success of companies including non-profit institutions are finance, customer, internal business process, and growth and communication. The concept of organizational achievement is a challenge for researchers. Vanderstraeten et al. (2014) suggested that innovation, communication, internal business process, customer, and finance are the dimensions used to assess organizational success. Moreover, Maltz et al. (2003) explained that to measure organizational success is a challenge for managers and researchers.

From the entrepreneurial point of view, finance and non-finance dimensions are not enough to direct organizations to achieve optimal performance. The results of Sedyowidodo et al. (2017) revealed that it is not easy for organizations, such as SOEs, to achieve optimal performance. As one of the economic pillars owned by the state, the entrepreneurial instinct of SOEs is still considered less sharp than private companies. The entrepreneurial instinct referred to here is to see and take the opportunities to build a business. Therefore, the competitiveness of SOEs is very far lower than that of private companies and, on the average, new SOEs will start being competitive when private companies have succeeded. The success of achieving optimal performance is influenced by the courage to take risks and innovation based on the results of a constructive communication process of each member of the organization.

\section{LITERATURE REVIEW}

Entrepreneurial Orientation. Entrepreneurial orientation is defined as a process of making business strategies and behaviors that can be identified through the characteristics of innovativeness, proactiveness, risk-taking, competitive aggressiveness and autonomy, facilitation to pursuit opportunities (Lumpkin and Dess, 1996; Lumpkin et al., 2009). Avlonitis and Salavou (2007) said that entrepreneurial orientation consists of organizational phenomena reflecting the managerial capacity to act proactively and aggressively to win the 
competition. Moreover, Zhou and Wu (2010) explained that proactiveness and decision making have a positive effect on the number of innovations produced in a business, but both dimensions do not affect the adoption of innovation. Meanwhile, according to Ma'toufi (2015), entrepreneurial orientation affects open-mindedness and the number of innovations produced by a business. In linear, Mandhousi et al. (2011) stated that entrepreneurial orientation has an effect on innovation performance, directly or indirectly through knowledge management.

According to Miller (1983), entrepreneurial orientation includes three dimensions, namely innovativeness, proactiveness and risk-taking. Innovativeness is the ability and willingness of companies to support creativity, new ideas, and experimentation (Lumpkin and Dess, 1996). Proactiveness (being proactive) is to pursue competitive opportunities and competition in anticipating future needs and forming a business environment (Lumpkin and Dess, 2001). Risk taking is an effort to devote resources to business with opportunities to not only gain profits but also to take into account the possibility of failure (Miller and Friesen, 1982; Lumpkin and Dess, 1996). The courage to take risks is also associated with entrepreneurial behavior because successful entrepreneurs are usually people who dare to take risks (Kuratko and Hodgetts, 2001). The questionnaire developed by Covin and Slevin (1989) is used to measure the entrepreneurial orientation of companies. Covin and Slevin (1989) also developed three dimensions, namely Innovativeness, Proactiveness, and RiskTaking, measured at a five point-Likert scale based on the study of Miller and Friesen (1982). Furthermore, Lumpkin and Dess (1996) proposed two additional dimensions in the construct of entrepreneurial orientation, namely competitive aggressiveness and autonomy. Competitive aggressiveness is the intensity of effort to defeat competitors and characterized by a strong attacking attitude to threats of competition. Autonomy refers to independent actions taken by individuals or teams to ensure that ideas and concepts are properly resolved. Autonomy provides employees with opportunities to perform effectively through independent, self-directed and creative actions (Lumpkin and Dess, 1996).

In summary, the most studied dimensions are respectively Proactiveness, Risk Taking and Innovativeness. That is, the most used dimensions to measure Entrepreneurial Orientation are Proactiveness, Risk Taking, and Innovativeness.

Corporate Performance. The use of performance measurement systems is often recommended to facilitate strategy implementation and improve performance (Davis \& Albright, 2004). Companies are not only required to give values to shareholders but also stakeholders and it is proved that performance measurement systems can facilitate it (Ittner and Larcker, 2003). Some models and frameworks identified are Strategic Measurement and Reporting Technique (SMART) (Cross \& Lynch, 1989), the Performance Measurement Matrix (Keegan et al., 1989), Results and Determinants Framework (Fitzgerald, Johnston, Brignall, Silvestro \& Voss, 1991), Balanced Scorecard (BSC) (Bhagwat \& Sharma, 2007; Kaplan \& Norton, 2001), Cambridge Performance Measurement Systems (CPMS) Design Process (Neely et al., 1996), Integrated Performance Measurement Systems (IPMS) (Bititci \& Carrie, 1998), Performance Prism (Neely \& Adams, 2001), FFQM Business Excellence Model (EFQM, 1999).

Currently, performance measurement systems consisting of the use of financial and non-financial indicators are associated with business strategies, such as balanced scorecards (BSC) (Kaplan and Norton, 2001) and multi-criteria key performance indicators (KPI) and usually called as Contemporary Performance Measurement (CPM) (Cheng et al., 2007; Hall, 2008). A survey conducted by Van der Stede, Chow, and Lin (2006) concluded that organizations with extensive performance measurement systems, including non-financial subjective and objective measurement, can achieve better performance. According to Franco-Santos, Lucianetti \& Bourne (2012), a performance measurement system is a measurement used to operate corporate strategies, including financial and non-financial indicators. A performance measurement system is a system adopting BSC (Kaplan and Norton, 1992, 1996, 2001), performance prism (Neely et al., 2002), levers of control framework (Simons, 1995) and KPI because it is connected with business strategies. In this 
increasingly competitive era, performance measurement is a strategic activity that will determine company sustainability.

Organizational Communication. Since 1990, communication has constituted a critical differentiator between organizations and has become a phenomenal topic attracting many researchers (Jyothibabu, Farooq, and Bhusan Pradhan, 2010). Organization communication is being widely discussed by a lot of literature in various fields of research ranging from health, work safety to information systems and the world of education (Atwood, Mora, and Kaplan, 2010). Through communication, organizations can adapt to the environment, prevent repeat errors, and preserve knowledge which is potentially lost (Dixon, 1993). Its multidisciplinary nature enables researchers to see it from various perspectives, including psychology, sociology, and organizational theories (Tohidi et al., 2012).

Organizational communication occurs when all people in the organization can together develop their capacity to achieve results as expected, where all new thoughts are fostered, and the people can aspire ideas freely so that they can learn to work together continuously (Senge and Sterman, 1992). Meanwhile, according to Fang, Chang, and Chen (2011), organizational communication capacity is a factor facilitating organizational communication processes or a factor encouraging organizations to learn. This research used the definition of organizational communication from DiBella et al. (1996) and Tjakraatmadja \& Lantu (2006) stating that organizational communication is a process to help organizations create, move, and integrate knowledge and skills as well as learn to improve their knowledge continuously. Organizational communication involves the cognitive aspect and behavioral changes (Argyris \& Schön, 1996; Senge \& Sterman, 1992).

There are various communication models that can be used as concepts for managing organizational communication. The communication model developed by Knowles (1981) with an adult approach consisting of five stages of activity, namely a) problem definition, b) information collection, c) identification of alternative problem solving, d) decision making, and e) action implementation can be an option. Skerritt (1995) revealed that educational management for organizational communication is by communication action. Information processing models are based on the assumption that communication processes are the formation of the association between response stimuli. The main focus of information processing models are the internal conditions constituting barriers between stimuli and responses. Participants learn to be active and process information obtained about an object. Another assumption is that humans receive information, store and take it when needed while processing information is the cognitive activity. Hase and Kenyon (2001) proposed heutagogy as the natural development of the previous educational methodology and the optimal communication approach in the 21st century. Heutagogy is a holistic framework for creating independent learners. Msila \& Setlhako (2013) stated that heutagogy underlines the idea of learning how to learn. Moreover, according to Arnett \& Ecclesfield (2015), heutagogy is independent communication. Meanwhile, Salim (2015) defined Self-Directed Communication (SDL) as a relatively new concept for adult education.

Schung (2013) suggested that a personal model is one's self-regulation model. A person learns to organize himself based on his comparison of other behaviors which are choices to be realized in the form of behaviors. The actors in this model regulate which behaviors will be shown. The actors learn to build differentiating stimuli when their behaviors appear, provide their own teaching when needed, and conduct self-assessment of behavioral performance to determine whether the desired behavior occurs. Besides, self-monitoring, self-teaching, and implementation are the key to the personal communication model.

The third communication model is the social model. In this model, one learns based on his interaction with the social situation. The assumption in social communication is that social behavior and environment influence each other. Communication is an act of processing information. The information referred to here is about behavior structures and environmental events transformed into symbolic representations forming the basis for behavioral demands. This model was developed based on the perspectives proposed by Walters (1981) on selfefficacy. Lyons \& Bandura (2017) suggested that CBM (Case-Based Modelling) relates to individual and group communication, reflective practices, and growth of mindset. The whole 
instructional approach is explained in detail along with its consequences and benefits. CBM is based on Experiential Communication Theory (ELT) and Self-Regulation of Communication (SRL) theory.

Hypothesis. Performance is related to entrepreneurial orientation. Being proactive and courageous in taking risks can increase organizational growth and communication. Besides, proactive behavior can optimize market opportunities so as to impact market share. Companies that have the ability and willingness to support creativity, new ideas, and experimentation can expand market share and increase customer satisfaction. Proactive behavior is to pursue competitive opportunities and competition in anticipating future needs and forming a business environment (Lumpkin and Dess, 2001). Meanwhile, the courage to take risks is a condition that will direct how internal business processes take place.

Miller (1983) asserted that EO (Entrepreneurial Orientation) is a strategic construction that reflects the extent to which a company is innovative, proactive, and courageous in taking risks in a strategic posture. Lumpkin and Dess (1996) described the relationship between EO and Performance moderated by environmental and organizational factors. According to Zhao et al. (2011), Organizational Communication (OC) with Experimental Communication design was the intervening variable of the relationship between Entrepreneurial Orientation (EO) and Corporate Performance (CP). Experimental communication design has increased the performance of companies in China. Previously, Li et al. (2009) obtained that the process of knowledge creation moderates the relationship between EO and performance. Moreover, Su et al. (2011) found the direct relationship between EO and Corporate Performance while Jantunen et al. (2005) found dynamic capabilities as the intervening variable of the relationship between EO and Performance. Lee \& Lim (2009) and Kraus et al. (2012) also stated that EO and Performance have a direct relationship. Based on the research context and literature review, the researchers formulated these following hypotheses:

Ha1: EO has a positive effect on OC;

$\mathrm{Ha2}$ : $\mathrm{OC}$ has a positive effect on $\mathrm{CP}$;

Ha3: EO has a direct positive effect on CP.

\section{METHODS OF RESEARCH}

Based on the purpose and statement of the problem, this research belonged to a verificative descriptive research in which the data were collected through a survey on SOEs in Indonesia. The sampling of SOEs was done using a probabilistic sampling design or called a random sampling technique. The primary data were sourced from the observation unit, referring to the sampled SOE managers. The respondents' answers to the questionnaires, consisting of SOE Entrepreneurial Orientation, Organizational Communication, and Performance variables, were the primary data. Entrepreneurial Orientation was measured based on the dimensions of Innovativeness, Risk Taking, and Proactiveness. Corporate Performance was measured based on Customer Satisfaction, Finance, Internal Business Process, and Communication/ Growth. Meanwhile, Organizational Communication was measured based on Continuous Communication, Discussion and Request for Information, Groups, Employee Empowerment, Connection Systems, Applied Systems, and Leadership. The data were then analyzed using SEM-PLS method.

\section{RESULTS AND DISCUSSION}

The research results showed that the Entrepreneurial Orientation was quite diverse yet tended to be good in general. Based on the results depicted in the diagram, Innovativeness, Proactiveness and Risk-Taking were in the category of "Quite Good". 60\% respondents stated that the Entrepreneurial Orientation of SOEs in Indonesia was "Quite Good", "Good", and "Very Good" while the other $19 \%$ decided to be neutral. The rest $21 \%$ respondents argued that the Entrepreneurial Orientation of SOEs in Indonesia was "Quite Bad", "Bad" and "Very Bad". From the measurement model, it was obtained that the dimensions of 
Entrepreneurial Orientation that have the biggest contribution were Innovativeness, Proactiveness, and Risk Taking.

From the Customer Satisfaction dimension, the condition of SOE performance was perceived heading to the "good" category. The dimension of Communication and Growth ranked the highest with an average index of 4.2 (Good), followed by Customer Satisfaction of 4.13 (Moderate), Finance of 4.01 (Moderate) and Internal Business Process of 3.98 (Moderate). Meanwhile, the intrapreneurship was perceived high with an average index of 4.4. A self-determined goal setter is someone who initiates to do a particular task demanded by his own interest. The most contributing indicators on the SOE Performance variable were Internal Business Process, Finance, Customer Satisfaction, and Communication and Growth.

The criteria used for internal consistency reliability were Cronbach's alpha, Composite Reliability (CR) and rho A. The measurement model would be said to meet the criteria if the value of each reached $>0.7$. The greater value indicated a higher reliability

Table 1 - Evaluation of Measurement Model Consistency

\begin{tabular}{|l|l|l|l|}
\hline $\mathrm{n} / \mathrm{n}$ & Cronbach's Alpha & rho_A & Composite Reliability \\
\hline Entrepreneurial Orientation & 0.781 & 0.813 & 0.873 \\
\hline Organizational Communication & 0.896 & 0.902 & 0.918 \\
\hline SOE Performance & 0.853 & 0.903 & 0.898 \\
\hline
\end{tabular}

Source: Processed Research Results (2017).

The effect of Entrepreneurial Orientation in SOE Performance through Organizational Communication in the structural model was analyzed through two paths. The first path was the effect of Entrepreneurial Orientation on Organizational Communication with a path coefficient $\left(V_{11}\right)$ of 0,605 and $t_{\text {count }}$ of 8.824. The second path was the effect of Organizational Communication on SOE Performance with a path coefficient $\left(\beta_{3}\right)$ of 0.14 and $t_{\text {count }}$ of 0.814 . If calculated, the effect of Entrepreneurial Orientation on SOE Performance through Organizational Communication was $0.605 * 0.140 * 100 \%=8.47 \%$. That is, $8.47 \%$ of the SOE Performance was influenced by Entrepreneurial Orientation through Organizational Communication while the $91.53 \%$ was influenced by other factors. Furthermore, according to the calculation, it was obtained that the VAF was $27 \%$, indicating that Organizational Communication partially provided a mediating effect on SOE Performance. The indirect effect of EO on SOE Performance through Organizational Communication was bigger than the direct effect which was actually negative. Organizational communication is a process requiring structural support and ultimately becoming a culture within an organization.

Managing communication is the conceptual framework to increase the function of organizational communication as a moderation between EO and Performance. Organizations are the entity of individuals that have the ability to learn. According to Argyris \& Schön (1996) and Senge \& Sterman (1992), organizational communication involves the cognitive aspect and behavioral changes. On the other side, Senge (1990) and Slater \& Naver (1995) divided communication into two, namely generative and adaptive communication. That is, the management of organizational communication is based on the assumption that the process (generative communication) is a cognitive and mental process to generate radical changes while adaptive communication produces changes gradually in organizations.

The approach to managing Organizational Communication cannot be separated from the assumption about cognitive learning processes, which then expand to other processes, including social role learning. The model of social learning shows a direct relationship between self-efficacy perceived by a person and behavioral changes (Walter, 1978). In linear, Lyons \& Bandura (2017) suggested that communication produces a performance script (behavior) that can be forged with the aim to increase communication and performance. Communication occurs by way of practices through actual actions or by way of experiencing it through other people, that is by observing the models who do it. There are four factors that can encourage the imitation of individuals, namely individual permanent characteristics, circumstances, goals and stimuli. Communication is associated with adults as expressed by Knowles (1984) or Freire (1978) in their studies on reflection and liberation. 
Generating effective communication with adults requires collaboration and regularity in managing every aspect related to communication. It is in accordance with the assumption of adults.

The concept of information processing in this technological era is translated into heutagogy learning activities as expressed (related to information technology) along with the development of communication functions. Similarly, Hanse \& Kenyon (2001) and Blaschke \& Hase (2016), communication processes in SOEs can expand the role of individuals to optimize performance through ideas and knowledge that can generate values. Virtual collaboration extends access to knowledge and innovation simultaneously, and technological convergence facilitates the increase of learning activities with technology. With global connectivity, the whole world is connected. Online communities get involved in meaningful conversations and non-participant social activism which is oriented to problem-solving. Digital creativity builds employees' creative ability and power to create values. That is, the existing conditions can function as an independent learning space for employees in SOEs.

The conceptual framework for managing organizations to learn sustainably not only uses a one-disciplinary approach. Instead, a multidisciplinary approach will provide a better basic construction to understand how organizational communication processes are oriented towards organizational performance. Besides, a multidisciplinary approach is based on the assumption that individuals in organizations are learners and adults in the era of information and technology. Management of organizational communication models focuses on the explanation of the relationship between variables in the communication process (input, process, output) as an open arrangement because there is an exchange process between the communicating system and the environment as well as a paradigm shift as a result of self-organizing carried out continuously. In addition, the high level of intrapreneurship that hampers organizational performance encourages the need for a personal model as a communication model applied in SOEs. This model is related to individual self-regulation. The model selection in organizational communication itself is based on various considerations such as behavioral control, value proximity, usefulness. The development of organizational communication models is defined as a conceptual design engineering process in an effort to improve the model function through the addition of communication components. Moreover, the development of organizational communication models can also be interpreted as an effort to expand or realize organizational potentials.

Research Limitations and Implications. This research only involved SOEs in developing countries with the assumptions that individual intrapreneurship of the organizational members was still strong and the autonomy in the management of SOEs by policymakers was weak. Furthermore, the communication model managed were limited to personal and social information processing models.

\section{CONCLUSION}

The effect of EO on organizational performance is moderated by organizational communication. The models developed in communication include information processing model, personal model, and cognitive model with various assumptions to obtain a more constructive understanding of communication. Managing communication with multidisciplinary assumptions in SOEs is an effort to optimize the effect of EO on institutional/ organizational performance on an ongoing basis.

\section{REFERENCES}

1. Andreas Rauch, Johan Wiklund, G. T. Lumpkin, Michael F. (2009) Entrepreneurial Orientation and Business Performance: An Assessment of Past Research and Suggestions for the Future. Published in: Entrepreneurship Theory and Practice, in press

2. Argyris Chris \& Schön Donald A.(1996). Organizational Communication. 2. Theory, method, and practice: Addison-Wesley Arnett and Ecclesfield 
3. Atwood, Mora \& Robert K. (2010). Communication to lead: evaluating leadership and organizational Communication. Leadership \& Organization Development Journal, 31(7), 576-595.

4. Avlonitis, George \& Salavou, Helen. (2007). Entrepreneurial Orientation of SMEs, Product Innovativeness, and Performance.Journal of Business Research. 60. 566-575.

5. Bhagwat, R., \& Sharma, M. K. (2007). Performance measurement of supply chain management: A balanced scorecard approach. Computers and Industrial Engineering, 53(1), 43-62.

6. Bititci U S, \& Turner, T. (1989).Dynamics of Performance Measurement Systems, International Journal of Operations and Production Management, Vol 20, no. 6, pp 692704,

7. Covin, G., Slevin, D., \& Slevin D.P. (1988). T H E Influence of Organization Structure. Journal of Management Studies, 109 (May), 321-334.

8. Covin, JG. Slevin, DP. (1989). Strategic Management of Small Firms in Hostile and Benign Environments. Strategic Management Journal 10: 75-87.

9. Cross K F and Lynch R L. (1989). The Smart way to define and sustain success", National Productivity Review, vol. 9, no 1, 1988-1989, pp 23-33.

10. David F Larcker, Taylor Randall, Itner, C.D, Larcker, D.F \& Randal, T.(2003). Performance implications of strategic performance measurement in financial services firms.Accounting, Organizations and Society, 28(7), 715-741.

11. Davis, S., \& Albright, T. (2004). An investigation of the effect of Balanced Scorecard implementation of financial performance. Management Accounting Research, 15(2), 135153.

12. Dess, G.G, Ireland,RD, Zahra SA, Floyd,S.W, Janney, JJ \& Lane, P.J. (2003). Emerging issues in corporate entrepreneurship. Journal of management, 29(3), 351-378.

13. Dixon N. (1993). Developing managers for the Communication organization. Human Resource Management Review, 3(3), 243-254.

14. Edwin, Nevis \& Gould, Jannet M, G. (1995). Understanding organizational Communication capability. Journal of management studies, 33(3), 361-379.

15. (1996). Understanding organizational Communication capability. Journal of management studies, 33(3), 361-379.

16. Enyon, C., \& Hase, S. (2001). Moving from andragogy to heutagogy in vocational education. Proceedings of the 4th Annual Australian Vocational Education and Training Research Association (AVETRA) Conference, 8.

17. Fang, Chang H \& Chen, G.L.(2011). Organizational Communication capability and organizational innovation: The moderating role of knowledge inertia. African Journal of Business Management, 5(5).

18. Fox J.M (2005).Organizational Entrepreneurship And The Organizational Performance Linkage In University Extension. Ohio State University. Dissertation.

19. Franco, Santos, Lorenzo Lucianetti \& Mike, B. (2012). Contemporary performance measurement systems: A review of their consequences and a framework for research. Management Accounting Research, 23(2), 79-119.

20. Jantunen, A. (2005). Entrepreneurial Orientation, Dynamic Capabilities and International Performance. Journal of International Entrepreneurship, 3, 223-243.

21. Joseph F Hair, Jr. William C Black, Barry J Babin, \& Ralph E.(2014). Multivariate data analysis: Pearson new international edition: Upper Saddle River, NJ: Pearson Higher Education.

22. Kaplan, Robert \& David, N. (1996a). Linking the balanced scorecard to strategy. California management review, 39(1), 53-79.

23. (1996b). Using the balanced scorecard as a strategic management system: Harvard business review Boston, MA.

24. Kaplan, R. (2001). Strategic Performance Measurement and Management in Nonprofit Organizations. Nonprofit Management \& Leadership, 3(Spring), 353-370.

25. Kaplan, R. S dan Northon., D, P. (1996). Putting the Balanced Scorecard to Work. harvad Business Review. 
26. Kaplan, S.E. and Wisner, P.S. (2001), "The judgmental effects of management communications and fifth balanced scorecard category on performance evaluation", Behavioral Research in Accounting, Vol. 21 No. 2, pp. 37-56.

27. Keegan, Daniel P \& Eilier, R.G.(1989). Management Accounting; Montvale Vol. 70.Iss. 12,45

28. Knowles, M (1981). Andragogy in action.California; Jose Bass.

29. Kraus, S., Rigtering, J. P. C., Hughes, M., \& Hosman, V. (2012). Entrepreneurial orientation and the business performance of SMEs: a quantitative study from the Netherlands. Review of Managerial Science, 6(2), 161-182.

30. Lee, S. M., \& Lim, S. (2009). Entrepreneurial orientation and the performance of service business. Service Business, 3(1), 1-13.

31. Li, YH. Huang, JW. Tsai, MT. 2009. Entrepreneurial Orientation and Firm Performance: The Role of Knowledge Creation Process. Industrial Marketing Management 38(4), 440449.

32. Lumpkin, G. T., \& Dess, G. G. (1996). Clarifying the entrepreneurial orientation construct and linking it to performance. Academy of Management Review, 21(1), 135-172.

33. Lumpkin, G. T., \& Dess, G. G. (2001). Linking two dimensions of entrepreneurial orientation to firm performance: The moderating role of environment and industry life cycle. Journal of Business Venturing, 16(5), 429-451.

34. Lumpkin, GT. Dess, GG. (1996). Clarifying the Entrepreneurial Orientation Construct and Liking It to Performance. Academy of Management Review. 21(1): 135-172.

35. Lyons. P \&R., P Bandura (2017)Coaching to enhance self-regulated Communication. Human Resource Management International Digest, 25(4), 3-6.

36. Madhousi, Mehrdad, Abdolrahim Sadati, Hamidreza Delavari, Mohsen, M. (2011). Entrepreneurial Orientation and Innovation Performance: The Mediating Role of Knowledge Management, Asian Journal of Business Management, 3(4), 310-316.

37. Maltz, A. C. C., Shenhar, A. J., \& Merino, D. N. N. (2003). Defining and measuring organizational success: toward a dynamic, multi-dimensional model. PICMET '01. Portland International Conference on Management of Engineering and Technology. Proceedings Vol.1: Book of Summaries (IEEE Cat. No.01CH37199).

38. Ma'toufi, AR \& Tajeddini, K (2015). The impact of Communication orientation on entrepreneurial orientation and innovation in small-sized business firms. Middle East Journal of Management, 2(3), 252-267.

39. Mathew, Hall. (2008). The effect of comprehensive performance measurement systems on role clarity, psychological empowerment and managerial performance. Accounting, Organizations and Society, 33(2), 141-163

40. Miller, D. (1983). The correlates of entrepreneurship in three types of firms. Management Science, 29(7), 770-79.

41. Miller, D. Friesen, PH. (1982). Innovation in Conservativve and Entrepreneurial Firms: Two Models of Strategic Momentum. Strategi Management Journal Vol 3(1).1-25.

42. Miller, D. Friesen, PH. (1982). Innovation in Conservativve and Entrepreneurial Firms: Two Models of Strategic Momentum. Strategi Management Journal Vol 3(1).1-25.

43. Msila, V., \& Setlhako, A. (2012). Teaching (still) Matters: Experiences on Developing a Heutagogical Online Module at UNISA. Procedia - Social and Behavioral Sciences, (69), 136-142.

44. Neely Andy, Mike Gregory, \& Ken P. (1995). Performance measurement system design: A literature review and research agenda. International Journal of Operations \& Production Management. 25(12), 1228-1263.

45. Salim.A.M. (2015). When Life Satisfaction among Adult Learners is at Odds with their Attitudes, Willingness, and Perception: Confronting the Self-Directed Communication) International Journal of Innovation and Applied Studies10 No. 1 Jan, pp. 313-324.

46. Schumpeter, J. A. (1934). The theory of economic development: An inquiry into profits, capital, credit, interest, and the business cycle (Vol. 55): Transaction publishers.

47. Schunk, D, H. (2013) Communication Theories. NY. Pearson Education. 
48. Sedyowidodo, U.A., Basbeth, F.B., Sule, E.T.C. (2017). Entrepreneurial orientation and business performance: The mediating role of organizational Communication and innovation in state owned enterprise (SOE) in Indonesia. Journal of Engineering and Applied Sciences, 12, 417-429

49. Senge, Peter M \& Sterman, D. (1992). Systems thinking and organizational Communication: Acting locally and thinking globally in the organization of the future. European journal of operational research, 59(1), 137-150.

50. Senge, Peter M.(1997). The fifth discipline. Measuring Business Excellence, 1(3), 46-51.

51. Simons, R. L. (1995). Levers of control: how Mqnqgers use innovative control system to drive strategic renewal. Harvard Business School Press. USA

52. Skerritt, Z \& Kerritt, O. (1995). Developing a Communication organization through management education by action Communication. The Communication Organization, 2(2), 36-46.

53. Su, Z., Xie, E., \& Li, Y. (2011). Entrepreneurial orientation and firm performance in new ventures and established firms. Journal of Small Business Management, 49(22), 558577.

54. Tjakraatmadja, L. (2006). Knowledge management dalam konteks organisasi pembelajar. SBM ITB, Bandung.

55. Tohidi, Seyedaliakbar \& Mandegari M. (2012). Organizational Communication measurement and the effect on firm innovation.Journal of Enterprise Information Management, 25(3), 219-245.

56. Van der Stede, W.A., Chow, C.W. and Lin, T.W. (2006).Strategy, choice of performance measures, and performance.Behavioral Research in Accounting.Vol. 18, pp. 185-205.

57. Walters. B, (1981).Self-referent thought: A developmental analysis of self-efficacy. NY: Cambrisge Universoty Press

58. Zhou, K.Z., Wu.F (2010). Technological capability, strategic flexibility, and product innovation.Strategic Management Journal, 31(5), 547-561. 